УДК 355:069“1989/1996”

DOI: $10.33099 / 2707-1383-2020-38-4-129-143$

Карпов В.В., доктор історичних наук, дочент кафедри міжнародних відносин та суспільних наук, Національний університет біоресурсів та природокористування Украӥни (м. Київ, Украӥна)

ORCID: https://orcid.org/0000-0002-3446-9187

\title{
ФОРМУВАННЯ ВІЙСЬКОВОЇ МУЗЕЙНОЇ СПРАВИ В УКРАЇНІ У ПЕРІОД СУСПІЛЬНО-ПОЛІТИЧНОЇ ТРАНСФОРМАЦІї (1989-1996 рp.)
}

\begin{abstract}
Мета дослідження полягає у висвітленні діяльності військових музеїв за часів зміни иіннісних орієнтирів суспільства і трансформації держсавного устрою та формування основ музейної справи у Збройних Силах Украӥни. Методи дослідження. Системність та комплексний підхід у розкритті мети, застосування порівняльного аналізу, історико-хронологічного, біографічного, історіографічного методів сприяло отриманню вагомих теоретичних результатів. Наукова новизна дослідження полягає в постановиі та розробиі актуальної теми, яка в науковому вимірі отримала недостатнє висвітлення і досліджується на емпіричному досвіді. Обгрунтовано ідею, яка полягає в тому, щзо діяльність військових музеїв не завжди відповідає потребам суспільства, вимагає державного регулювання і підтримки. Висновки. Констатується, щуо військове музеєзнавство в досліджуваний період відзначалося пошуком нової моделі функиіонування військових музеїв, щуо було продиктовано змінами суспільних настроїв, політичного та економічного устрою. Відзначено, щз в радянський період така модель була розроблена Музеєм історії військ Далекосхідного військового округу і полягала в наданні музею самостійності в прийнятті рімень оперативного управління його діяльністю. Однак, зміни ціннісних орієнтирів привели до зниження ролі музеїв в суспільному прочесі. Така модель була покладена у створення Музею Збройних Сил Украӥни, як системоутворючого елементу військової музейної справи.
\end{abstract}

Ключові слова: військовий музей, збройні сили, СРСР, Украӥна, суспільство, ияінності, трансгресія.

Актуальність теми. Військове музеєзнавство в Україні має драматичну, а подекуди і трагічну історію. Ініціатива створення в кінці XIX століття у Києві Військового народного музею не знайшла громадської підтримки [1, 254]. Військово-історичний музей Київського відділу Імператорського Російського військово-історичного товариства, відкритий в 1910 році, не мав власно- го приміщення і тому експонати були розміщені в іншому музеї. У період Визвольних змагань 1917-1921 рр. спроба створення музею в Армії Української Народної Республіки була реалізована, але виявилася мало результативною $[2,5]$. У радянський період в Києві діяв Музей історії військ Київського військового округу, який після 1991 року був ліквідований. Формування 
i становлення військово-музейної справи в сучасних умовах проходить в складних суспільно-політичних обставинах подальшого утвердження української державності [3]. Для успішності цього процесу важливим і наразі актуальним є осмислення історичного досвіду військового музеєзнавства в період зламу епох, що дозволяє окреслити перспективи розвитку української військово-музейної справи.

Аналіз існуючих досліджень і публікацій. Загальна стратегія дослідження розвитку військового музеєзнавства демонструє тенденцію до виявлення тих явищ, які, не дивлячись на різноманітність, демонструють загальні тенденції і особливості діяльності музеїв. До зазначеної стратегії відносяться роботи В. Машталіра, В. Котвіцкого, Л. Міненко, Ж. Денисюк, О. Мокроусової, Р. Маньківської, І. Пістоленко, С. Руденко. Дослідники аналізують процес становлення військово-музейної справи в Україні. Виклад основного матеріалу статті доповнюється особистими архівними матеріалами автора i його досвіду керівництва Музеєм історії військ Далекосхідного військового округу в період (1985-1991) та створення і реформування Музею Збройних Сил України (1995-1996).

Мета дослідження полягає у висвітленні процесу формування та діяльності військових музеїв за часів зміни ціннісних орієнтирів суспільства і трансформації державного устрою та формування основ музейної справи у Збройних Силах України.

Виклад основного матеріалу. Перебудова радянського суспільства, оголошена партійно-державним керівництвом Радянського Союзу, відгукнулася негативно на добробуті людей. Це стало очевидним відразу - 2 квітня 1991 року відбулося підвищення цін на продукти харчування, товари і послуги. Духовні потреби громадян поступилися місцем життєво необхідним потребам забезпечення елементарного проживання. Такі процеси прямо і негативно позначилися на діяльності музеїв, що виразилося різким зниженням кількості відвідувачів. Показовим в цьому є статистичні дані роботи Музею Далекосхідного військового округу в першому кварталі 1991 року. Кількість проведених заходів в квітні в порівнянні з березнем знизилася - 354 до 35, а відвідувачів вдвічі з 5489 до 2787 осіб. У той час як в січні було 3145 , в лютому 3507 відвідувачів. Цікаво, що це стосується і військовослужбовців - 3988 осіб у січні до 170 в квітні.

Поряд з об'єктивними проблемами в час перетворень визначилися і проблеми в організації діяльності військових музеїв. Найгострішою була проблема правового статусу музею - відповідно до Положення про військово-історичних музеях в Радянській армії і Військово-Морському флоті музеї військових округів були політико-просвітницькими установами, які були призначені для збору, зберігання і використання предметів матеріальної і духовної культури 3 метою виховання громадян і військовослужбовців. Вони підпорядковувалися політичним управлінням військових округів і флотів, а фінансово-економічне забезпечення покладалося на Будинки офіцерів округів. Такий стан на певному етапі повністю був виправданим. Однак, з часом музеї ставали загальнодоступними, відкритими для суспільства і це вимагало розробки нової моделі їх роботи.

Зміна концепції військових музеїв вбачалася в перетворенні їх з політико-просвітнього закладу на культурно-просвітній заклад, який проводить наукову роботу 3 виявлення, збору і зберігання військово-історичних пам'яток матеріальної та духовної культури, а також їх використання 3 метою формування історичної свідомості у відвідувачів. 


\section{ДІЯЛЬНОСТЬ МУЗЕЇВ ВІЙСЬКОВИХ ОКРУГІВ І ФЛОТІВ РАДЯНСЬКОЇ АРМІЇ І ВІЙСЬКОВО-МОРСЬКОГО ФЛОТУ СРСР [4] роки}

\begin{tabular}{|c|c|c|c|c|}
\hline № & Найменування музею & $\begin{array}{l}\text { Кількість } \\
\text { відвідувачів }\end{array}$ & $\begin{array}{l}\text { Проведено } \\
\text { заходів }\end{array}$ & $\begin{array}{c}\text { Кількість } \\
\text { надходжень }\end{array}$ \\
\hline 1. & $\begin{array}{l}\text { Музей історії військ Закавказського військового } \\
\text { округу }\end{array}$ & 72204 & 483 & 1000 \\
\hline 2. & $\begin{array}{l}\text { Музей історії військ Далекосхідного військового } \\
\text { округу }\end{array}$ & 71897 & 3707 & 840 \\
\hline 3. & $\begin{array}{l}\text { Музей історії військ Московського військового ок- } \\
\text { ругу }\end{array}$ & 68200 & - & - \\
\hline 4. & $\begin{array}{l}\text { Музей історії військ Забайкальского військового } \\
\text { округу }\end{array}$ & 66196 & 525 & 350 \\
\hline 5. & $\begin{array}{l}\text { Музей історії військ Приволжсько-Уральського } \\
\text { військового округу }\end{array}$ & 37840 & 1572 & - \\
\hline 6. & $\begin{array}{l}\text { Музей історії військ Прикарпатського військового } \\
\text { округу }\end{array}$ & 37643 & 542 & 196 \\
\hline 7. & Музей історії військ Одеського військового округу & 32310 & 1220 & 732 \\
\hline 8. & $\begin{array}{l}\text { Музей історії військ Сибірського військового ок- } \\
\text { ругу }\end{array}$ & 30772 & 560 & - \\
\hline 9. & $\begin{array}{l}\text { Музей історії військ Белоруського військового ок- } \\
\text { ругу }\end{array}$ & 19338 & 324 & 336 \\
\hline 10. & $\begin{array}{l}\text { Музей історії військ Прибалтійського військового } \\
\text { округу }\end{array}$ & 12129 & 424 & 500 \\
\hline 11. & $\begin{array}{l}\text { Музей історії військ Ленінградського військового } \\
\text { округу }\end{array}$ & 9600 & - & - \\
\hline 12. & $\begin{array}{l}\text { Музей історії військ Туркестанського військового } \\
\text { округу }\end{array}$ & - & - & 365 \\
\hline \multicolumn{2}{|r|}{ Всього за музеї військових округів: } & 458129 & 9357 & 4317 \\
\hline 13. & Музей Черноморського флоту & 192386 & 4563 & 240 \\
\hline 14. & Музей Північного флоту & 118240 & 1552 & 744 \\
\hline 15. & Музей Балтійського флоту & 53000 & 1259 & 711 \\
\hline 16. & Музей Тихоокеанського флоту & - & - & - \\
\hline \multicolumn{2}{|c|}{ Всього за музеї флотів: } & 363626 & 7374 & 1695 \\
\hline \multicolumn{2}{|c|}{ Разом: } & 821755 & 13731 & 6012 \\
\hline
\end{tabular}

В цілому мова йшла про створення умов для реалізації закладеного в музеях морального потенціалу захисника Вiтчизни, який не міг розкритися повною мірою через існуючий стан речей. Концептуально слід було перетворити музеї «пам'ятники» в музеї військової історії. Військово-історичний музей бачився не як щось окреме, а скоріше як частина в загальному руслі розвитку музеєзнавства та історичної науки, і в цілому культури і суспільства, як сторона загальної культури, її кольоровий мазок в яскравій гамі людського творіння.

30 травня 1991 року в Окружному будинку офіцерів Ленінградського військового округу відбулися збори начальників військово-історичних музеїв військових округів і флотів. Головував на цих збоpax начальник управління культури Головного політичного управління Радянської армії і Військово-Морського флоту генерал-майор Якимів Віктор Іванович. Розглядалося питання посилення вій- 
ськово-патріотичного виховання та ролі в цьому музеїв. Проте, мова про зміну концепції діяльності військових музеїв не йшла.

На зборах були оприлюднені результати соціологічного опитування начальників музеїв. 50 респондентів показали, що політико-освітня, а в кінцевому рахунку виховна робота музеїв на 80 відсотків базується на військових традиціях і тільки 14 на революційних. Кожен четвертий вказав на відсутність матеріального забезпечення i кожен п'ятий на погані побутові умови. Що стосується можливості організації і ведення наукової роботи в музеях то 24 відсотки відповіли негативно, а 64 відсотки відзначили відсутність організаційного та матеріального забезпечення науково-дослідницької роботи. Кадровий потенціал музеїв на 55 відсотків складався 3 персоналу з досвідом роботи більше 15 років.

У питанні чи $є$ музеї вогнищами істоpiї показники знизилися з 84 в 1989 році до 75 відсотків у 1991 році. Пояснення тут може полягати в тому, що музейні експозиції були побудовані за принципом партійності, а в цей час в результаті політики плюралізму в радянському суспільстві почалися незворотні зміни громадської думки. Опитування показало зниження на 10-15 відсотків показників діяльності в 70\% музеїв, а також виникнення почуття розгубленості і невпевненості працівників музеїв в роботі, що була відсутня при опитуванні в 1989 році. Трансформація суспільних відносин давалася взнаки. Швидше це була деформація суспільства, трансгресивний перехід за межі усталених традицій, що призвело до різкої зміни ціннісних орієнтацій.

Після серпневих подій 1991 року це особливо стало відчутним. Начальник Центрального музею Збройних сил СРСР полковник Федоров Геннадій Андрійович висловлювався безапеляційно: «Хоча і була політика КПРС однобокою і привела до однобічного висвітлення історичного процесу розвитку суспільства, то теперішня політика може привести до дискредитації військово-музейної справи». За словами наукового співробітника Музею Далекосхідного військового округу Тамари Комаровської в музеї склалася гнітюча атмосфера — «не проводиться ніякої роботи, кожен день приходиш на роботу в музей і чекаєш неприємних новин». Станом на 27 листопада 1991 року з музею були звільнені 12 співробітників, а це майже половина. Склалася негативна тенденція заробляння грошей будь-яким способом хоча і на шкоду основної діяльності музею - заробити за всяку ціну, щоб зберегти основні фонди на плаву.

Військове музеєзнавство в переломні 1989-1991 роки зосередилося на пошуках нової моделі діяльності військових музеїв, що було продиктовано змінами суспільних настроїв, політичного та економічного устрою. Така модель була розроблена Музеєм історії військ Далекосхідного військового округу і їі суть полягала в наданні музею статусу окремої юридичної особи, що означало самостійність в ухваленні рішень оперативного управління його діяльністю. Це принесло позитивні результати. Однак, зміни цінністних орієнтирів і виникнення трансгресивних процесів в суспільстві призвели до зниження ролі музеїв в суспільному житті, що не дало можливості реалізувати таку модель.

Військове будівництво в Україні проходило під впливом цієї суспільно-політичної трансформації та характеризувалося багатьма протиріччями. Головне полягало у пошуку і спробі запровадження нових підходів до створення воєнної організації держави. Проте усталені роками військові традиції Радянської армії інерційно продовжували діяти. 
У гуманітарній сфері цей процес позначився ліквідацією соціально важливого інституту партійно-політичної роботи у військах та його носіїв політпрацівників. Натомість було запроваджено новітній інститут у цій сфері військового життя - coціально-психологічну службу. Структуру і завдання Соціально-психологічної служби Збройних сил України, до якої було включено і Музей Збройних сил України, та новітні принципи роботи 3 особовим складом запроваджував Володимир Савович Мулява. В.С. Мулява вийшов 3 горнила національно-визвольної боротьби за незалежність України та продовжував робити усе, аби в армії запровадити національно-патріотичний дух. Відоме його питання до офіцерів, які призначались на посади у війська: «Ви будете воювати проти Росії?» ставило їх у глухий кут. При вирішенні питання призначення заступником міністра оборони з озброєння генерал-лейтенанта Нестеренка Миколи Андрійовича, уродженця козацького краю, Мулява В.С. написав на його особовій справі, що він служив разом із останнім маршалом Радянського союзу Д.Т. Язовим, і це визначило долю патріотичного українця, яким офіцери та генерали знали М.А. Нестеренка ${ }^{1}$. Хоча, хто тоді не служив з Д.Т. Язовим ${ }^{2}$.

${ }^{1}$ Нестеренко Микола Андрійович (19352019), генерал-лейтенант, народився у селі Васильківка 28 січня 1935 року, що на Дніпропетровщині. Закінчив Харківське вище військове танкове командне училище, Бронетанкову академію та Академію Генерального штабу Збройних сил СРСР. Проходив службу на усіх командних рівнях, зокрема, був заступником Головнокомандувача Ставки військ на Далекому Сході (м. Улан-Уде). Завершив службу у 1991 році на посаді заступника командувача військами Одеського військового округу з озброєння.

2 Про свою службу із Д.Т. Язовим згадує начальник Генерального штабу ЗС України генерал-полковник А.В. Лопата // Лопата A.B.
Період існування Соціально-психологічної служби був нетривалим. Верх почали брати зрозумілі та усталені в Радянській армії правила і звичаї. Зі зміною керівництва Міноборони та призначення замість генерала Костянтина Морозова, який подав у відставку через незгоду із Президентом України Леонідом Кравчуком у питанні розбудови Збройних сил, генерала Віталія Радецького це особливо стало відчутним. Концепція роботи 3 особовим складом змінилася і на місце соціально-психологічної служби постала виховна робота. [5] За розподілом завдань у новоствореному Головному управлінні виховної роботи Мiністерства оборони України за музейний напрям відповідав начальник управління пропаганди генерал-майор Григорій Темко, чуйна та патріотична людина, українська за духом³. У вересні 1995 року Г.Д. Темко запропонував мені очолити Музей Збройних сил України та розпочати роботу з його формування. До цього часу я вже рік працював під його керівництвом на посаді офіцера управління з питань гуманітарної підготовки. За його словами на таке рішення його спонукала наявність у мене досвіду керівництва Музеєм Далекосхідного військового округу.

У справі призначення мене на посаду начальника Музею Збройних сил України не обійшлося без остаточного рішення - генерала Володимира Ситника, який у 1995 році очолив Головне управління виховної роботи Міністерства оборони України. Володимир Степанович на Далекому Сході очолював політичний відділ Тихоо-

Записки начальника Генерального штаба Вооруженных сил Украины. - К.: Издательский Дом «Военная разведка», 2014. — с. 203-265.

3 Темко Григорій Дмитрович, генерал-майор, народився у селі Томашівка, Недригайлівського району Сумської області, викладач, професор, доктор філософських наук, заслужений працівник культури. 
кеанської стрілецької дивізії. Він захоплювався музейною справою - музей дивізії завдяки його захопленню оновився і став кращим серед інших музеєм дивізії у Далекосхідному військовому окрузі. Саме у роботі над масштабною реекспозицією музею дивізії ми й познайомилися.

Призначення на посаду начальника музею відбулося після тривалого обговорення моєї кандидатури в Головному управлінні виховної роботи Міністерства оборони України та утвердження керівництвом Міністерства оборони України. 11 жовтня 1995 року відбувся наказ про моє призначення [6]. Це був початок нелегкого і тривалого шляху запровадження принципів музейної справи у діяльність Збройних сил України.

Проте ситуація виглядала так, що я виявися начальником музею на папері - caмого музею не існувало. Відчаю ніякого не було. Звичайно, краще обійняти посаду в установі у якій усе вже налагоджено. Цей виклик долі я сприйняв як можливість проявити свої професійні якості та досягти успіху. Досвід попередньої музейної практики засвідчив, що музей є елементом певної системи суспільних відносин. I якщо на Далекому Сході така система вже працювала то тут, в Україні їі необхідно було створити.

Концептуального бачення формування музею не існувало. Відсутнє було й уявлення про функції та завдання музею. Саме 3 цього й слід було розпочинати. Запропонований для розгортання штат музею не відповідав ніяким вимогам до діяльності музею державного рівня. Фактично це був набір посад, який свідчив про простакувате уявлення самої суті музею. Такого куцого штату не було у жодному музеї військового округу Радянської армії. Для порівняння, у Музеї Далекосхідного військового округу працювало 30 чоловік, а запропонований штат Музею Збройних сил України мав 14 посад. Зауваження щодо цього не були сприйняті і довелось розгортати музей за існуючим штатом. Все ж через очевидну його недосконалість було обіцяно переглянути та внести відповідні зміни, які слід було опрацювати. Саме розгортання штату було можливе тільки з січня 1996 року через невирішеність питання фінансування діяльності музею.

Протягом жовтня - листопада 1995 року вирішувалося питання про розміщення музею, де саме його розгортати, і у якій будівлі. Перше моє робоче місце не вийшло за межі кабінету управління пропаганди у $\mathrm{Mi}$ ністерстві оборони, де я проходив службу. Побратими допомогли поставити додатковий стіл та стілець і так я продовжив свою офіцерську службу та розпочав музейну діяльність в Україні.

В надрах управління ми обговорювали концепцію майбутнього музею та шляхи його розбудови. Активно брали участь в обговоренні перспектив розбудови музею генерал Григорій Темко, його заступник полковник Петро Костюк, офіцери управління Олександр Мельник, Андрій Алексієнко, Леонід Кукуруза, Андрій Куліш, Петро Зубченко, Олександр Бондаренко, Анатолій Малахов, а також працівники Збройних сил Наталія Забаштанська і Оксана Сакун. Проблема полягала у тому, як віднайти спосіб показу українського контенту військової історії, адже усі ми були носіями радянської ідеології і мали радянські уявлення про історію загалом. За період радянської влади була знищена будь-яка інформація про українську історію, окрім іiї радянського аспекту. І у час творення музею, пошуку його фундаментальних засад діяльності в Україні, за невеликим винятком, не було навіть літератури про історію Української держави та їі війська. У структурних підрозділах виховної роботи Збройних сил широко 
було розповсюджено репринтне видання 1953 року книги I. Крип’якевича «Історія Українського війська», яке було перевидане спочатку у 1992 році у Львові і вже потім у воєнному видавництві Міністерства оборони України «Варта» у 1994 році. Згодом у 1996 році Богдан Якимович видав книгу про історію українського війська у XX столітті. Власне ця література більше годилася до використання при підготовці та проведенні занять з гуманітарної підготовки. Для музейної практики вона виступала як джерело для опрацювання концепції побудови музейної експозиції і згодом була покладена в основу теорії висвітлення воєнної історії на теренах України. Проте, для реалізації цієї теорії бракувало самого головного - музейних предметів за відповідними історичними періодами.

Це була атмосфера творчості, адже у цей час творилися Збройні сили України і палких дебатів було немало. Різноманітні пропозиції щодо розбудови музею розглядались у Головному організаційно-мобілізаційному управлінні Генерального штабу Збройних сил України, офіцери якого приязно відносилися до ідеї створення музею. Все ж у кінцевому варіанті було прийнято рішення про розгортання музею на фондах Військово-історичного музею Центру культури, просвіти та дозвілля Збройних сил України, так у той час називався Центральний будинок офіцерів Збройних сил України. Відповідну директиву підписав начальник Генерального штабу Збройних сил України генерал-полковник Анатолій Лопата. Начальник Генерального штабу Збройних Сил України генерал Анатолій Лопата активно підтримав ідею створення Музею Збройних сил України. Його підтримка, виявлена появою директиви про розташування музею багато вартувала це був знак і сигнал для інших структур Міністерства оборони та Генерального штабу про необхідність підтримки та сприяння формуванню музею. Особливо це було важливим на фоні скорочення військових частин та військовослужбовців Збройних сил України та майже повного безгрошів'я у військах — офіцери по два-три місяці, а той по півроку не отримували грошового забезпечення.

За наказом Лопати А.В. музей розташували на фондах Військово-історичного музею Центру культури, просвіти та дозвілля Збройних сил України (ЦКПД ЗС України). Військово-історичний музей ЦКПД ЗС України мав гарну назву і тільки. Фактично це був спустошений, пограбований та розвалений Музей історії військ Київського військового округу. Мені поталанило бути на екскурсії у цьому музеї у 1987 році під час навчально-методичних зборів керівників музеїв військових округів та флотів, які організувало та провело Управління культури Головного політичного управління Радянської армії та Військово-морського флоту СРСР. Дводенні збори проходили у приміщенні Київського окружного будинку офіцерів. Учасники зборів, окрім офіційних доповідей про стан діяльності військових музеїв та завдань на перспективу, відвідали музеї міста Києва i, зокрема, Музей В.І. Леніна та, безумовно, Музей історії військ Київського військового округу.

Цей музей був багатий своєю колекцією, яка нараховувала понад 5 тисяч музейних предметів, і своєю експозицією, що була розміщена на двох поверхах і яка яскраво, із художнім смаком розкривала історію Червоної та Радянської армій на теренах України у межах дислокації підпорядкованих військових частин. Він не входив до числа провідних музеїв серед музеїв такого рівня, проте, був цікавим. У порівнянні із Музеєм Далекосхідного військового округу, який був розміщений в окремій будівлі площею 2300 м.кв., мав відкритий майданчик для 
військової техніки Музей Київського військового округу з його 700 м.кв. і невеличкою експозицією військової техніки виглядав, на мій погляд, як музей дивізії або армійського корпусу.

Музей у жовтні 1995 року виглядав інакше — це був повний розвал та занедбання. У приміщеннях гуляв вітер, двері на вході не зачинялись, чергова у під'їзді - Марія Василівна Мізюк - змушена була ховатися за колоною від холоду і вітру та бути постійно одягненою у верхній одяг. На стінах фойє ще висіла пожовкла наочна агітація радянських часів (це 1995 рік!). У туалет неможливо було зайти - у такому антисанітарному стані він був. Таке запустіння можна було тут побачити.

Начальник музею майор Ігор Лісодід, учасник війни в Афганістані, вимогливий офіцер, знаходився безпосередньо в експозиційних залах другого поверху разом із двома працівниками музею - такий був штатний розклад цього музею - іншого місця у них уже просто не було. В експозиційних залах першого поверху начальником політуправління Київського військового округу генералом Борисом Шаріковим у 1991 році був розташований комерційний банк. За словами Бориса Пацурова, завідувача Музею КВО, який на той час ще працював у ЦКПД ЗС України, експозиція першого поверху була просто викинута на вулицю у час коли він перебував у відпустці.

Практично на той час Будинок офіцерів являв собою скоріше бізнес-центр, аніж військовий культурно-освітній заклад. Орендарі в ЦКПД ЗС України були всюди. Через це музей займав тільки шість експозиційних залів другого поверху площею 300 м. кв. У цих шести залах збереглося створене у 1967 році експозиційне обладнання і тематичні комплекси періоду революції 1917 року та звільнення Києва у 1943 році. Вітрини були розібрані, експозиції, як такої, вже не існувало.

У невеличкому кабінеті завідувача музею знаходились Київська організація Спілки офіцерів України та громадська організація «Ліга Матері і сестри - воїнам України». Фонди музею Київського військового округу були майже відсутні. Приймати до Музею Збройних сил України за великим рахунком було нічого. 3 того, що залишилось комісія у листопаді розпочала відбір експонатів для музею. Проте, це було непросто. Облікова документація була неупорядкована і частково втрачена. Завідувач музею КВО Борис Пацуров ще не передав фонди своєму правонаступнику завідувачу Військово-історичним музеєм ЦКПД ЗС України майору Ігорю Лісодіду. Між ними постійно відбувалися суперечки щодо наявності фондів. І.Лісодід вимагав від Б. Пацурова звітності за відсутні експонати. На цьому фоні обидва зверталися до мене, як до третьої сторони, що має значний музейний досвід, для вирішення їх проблемних питань.

Як пізніше з'ясувалося, частина цих музейних фондів була вивезена до Центрального музею Збройних Сил СРСР, частина передана на зберігання до Українського музею історії Великої Вітчизняної війни, фонд зброї зберігався у колишньому Київському військово-інженерному радіотехнічному училищі зв'язку, а більша частина безповоротно була втрачена. Центральний музей Збройних Сил СРСР забрав з музею найбільш цінне - бойові прапори військових частин, нагороди та особисті речі видатних радянських воєнних начальників, які служили у Київському військовому окрузі.

Головне управління виховної роботи Міністерства оборони України вирішило прийняти до музею те, що залишилось, а питання відповідальності за збереження 
музейних фондів музею Київського військового округу віднести до компетенції керівництва ЦКПД ЗС України, адже Музей Збройних сил України не був правонаступником і попереду у нього була величезна робота з організації його власної роботи [8].

Такий стан музею Будинку офіцерів, нажаль, не був виключенням, а скоріше загальною тенденцією у військах - ситуація із музеями військових частин у цей період була катастрофічною. Працюючи у Музеї бойової слави дивізії, яка була розташована у Черкасах я побачив цілковите запустіння. До можливого його відвідання міністром оборони В.М. Шмаровим за одну ніч впорядкував те, що залишилось у музеї. Музей був розташований в окремій будівлі, але був повністю розкрадений. У ньому не залишилось жодної медалі чи ордена, оригінального документа. Залишились перехідні червоні прапори за роботу на цілині, які вочевидь не мали попиту на антикварному ринку. 3 музею 25-ї Чапаєвської дивізії, що дислокувалась у Лубнах збереглась тільки кулеметна тачанка, яка завдяки офіцеру, який забрав її додому і згодом вже навчаючись в Національній академії оборони України передав до Музею Збройних Сил України.

Працюючи у цей час в 3'єднаннях і військових частинах, що дислокувалися в гарнізоні міста Кривий Ріг полковник В.В. Котвіцький, офіцер Головного управління виховної роботи Міністерства оборони України неодноразово був свідком розвалу і спустошення музеїв танкового 3'єднання та ракетної військової частини.

На його думку загальне скорочення (передислокація, переформування) значної кількості органів військового управління, військових частин, військово-навчальних закладів, гарнізонних будинків офіцерів, установ та організацій, що дислокувалися на теренах України призводило до скорочення військових музейних установ. Музеї, як об'єкти військової культури, які донедавна були визнані безумовною цінністю держави, завдяки непродуманим рішенням керівництва знищувалися, або перебували під постійною загрозою ліквідації. У військових гарнізонах значна кількість музеїв була безслідно втрачена, лише окремі змінили свій статус і профіль. У зв'язку з реформуванням великої кількості військових частин i військово-навчальних закладів військово-музейна система в цей період розвалилася [9].

Ситуація в Україні загалом щодо збереження музейних фондів теж була вкрай загрозливою. Різке загострення криміногенної ситуації в країні, зростання цін на світовому ринку на предмети старовини та мистецтва, низький рівень музейної безпеки сприяли зростанню крадіжок з музеїв. Протягом 1993 - 1995 років з музеїв Волинської, Дніпропетровської, Закарпатської, Київської, Рівненської, Одеської областей, міста Києва та Автономної Республіки Крим було викрадено близько 3 тисяч музейних предметів [10].

Особливо цинічною є трагедія із Музеєм Прикарпатського військового округу. Це був один із кращих окружних музеїв у Збройних Силах СРСР. Приміщення було спроектоване саме для музею та побудоване на кошти особового складу військових частин і установ військового округу. Великі і просторі експозиційні зали, облаштовані музейні фонди, діорама написана художниками військової студії імені Грекова, рекреаційна зона, що включала світле фойє та територію поруч із музеєм, його розташування у міському парку імені Б. Хмельницького поруч із військовим меморіалом та Львівським вищим військово-політичним училищем, яке готувало офіцерів-культпрацівників свідчило про продуманість 
задуму при його створенні та функціональну актуальність. Музей використовувався як база для практики курсантів ЛВВПУ. У лекційному залі музею, обладнаному на той час новітніми технічними засобами проходили лекції з музеєзнавства, і я їх пам'ятаю, а самі курсанти проводили екскурсії у музеї і були його волонтерами.

У грудні 1995 року командувач Прикарпатського військового округу генерал П. Шуляк продав споруду музею комерційній компанії. Мене направили у Львів допомогти перевезти експонати 3 музею до іншого невеликого приміщення музею 24-ї Залізної дивізії, що був розташований на території 7-го полку цієї дивізії у Львові. Музей дивізії перемістили у Яворів. Морально було важко і на душі було гнітюче погано. Це був похорон колись славетного музею і моральний злочин перед військовою історією, ветеранами та суспільством. Цей випадок показав, що при створенні Музею Збройних сил України слід бути безкомпромісним, адже через таке ганебне ставлення до музеїв і збереження військової історії перешкод буде чимало.

Важким наслідком цього часу стало розкрадання музейних фондів та відвертий їх грабунок, як результат втрати статусу соціально значущого закладу в результаті зміни ціннісних орієнтирів суспільства. Власне ми стали на шлях захисту цих ціннісних орієнтирів - звитяги, доблесті і честі, а також пам'яті і музеїв, як їх осередків.

У роботі над створенням українського військового музею слід було опиратися на можливості колективу та свій власний досвід. Керівництво Міністерства оборони України не приділяло особливої уваги до становлення музею і не прийняло комплексного рішення з його розбудови. За таких умов слід було акумулювати власні сили задля ініціації та постановки питань 3 організації роботи музею на всіх стратегічних напрямках, задля отримання фінансового забезпечення, задля вирішення численних питань матеріально-технічного забезпечення музею перед керівниками Міністерства оборони та Генерального штабу Збройних сил, які врешті-решт були змушені їх позитивно розв'язувати.

Треба було починати роботу, але не було 3 ким. 33 січня 1996 року був введений в дію штат Музею Збройних сил України. За штатом в музеї нараховувалося два офіцери та 12 службовців. У 1996 році працювало: офіцерів - 1; службовців - 7. Першими працівниками музею стали Наталія Забаштанська, Оксана Сакун, які працювали у Головному управлінні виховної роботи МО України, Галина Смольянінова та Наталія Карпова.

Призначена наказом начальника Головного управління виховної роботи Мiністерства оборони України у листопаді 1995 року комісія для передачі фондів Військово-історичного музею ЦКПД ЗС України до музею завершила свою роботу 16 березня 1996 року. До музею були передані предмети 336 найменувань, а також облікова документація. Передані предмети належали до фондів колишнього Музею історії військ Київського військового округу і це були залишки багатої у минулому колекції.

Одночасно музеєм відпрацьовувалась концепція побудови майбутньої експозиції, яка була затверджена 20 квітня 1996 року начальником ГУВР МО України генерал-майором Ситником В.С. В концепції були закладені основні принципи роботи музею: повний і об'єктивний показ історичних подій, розкриття всіх періодів української військової історії у контексті суспільно-політичних подій, науковий підхід до становлення музею. Визначалось головне завдання музею - збирання, зберігання, обробка та використання пам'яток української військової історії з метою 
військово-патріотичного виховання військовослужбовців, усіх верств населення, пропагування досягнень військово-історичної науки, національно-історичних традицій Українського війська, а також сприяння розвитку військово-музейної справи у Збройних Силах України. Відповідно до концепції музей розглядався як головний елемент у системі військово-музейної справи в Збройних Силах України

Згідно 3 концепцією розширена тематична структура експозиції поділялась на чотири розділи. Розділ I — родовід Української армії, у якому сплановано висвітлити історію від княжої доби, козацьке військо, українські частини у складі імперій та військові формування в Україні у 1917-1920 роках. Розділ II - розвиток військової справи на теренах України (1921-1991рр.). Розділ III - проголошення незалежності та IV-й розділ - створення і розбудова Збройних Сил України та їх діяльність на сучасному етапі.

У концепції давалась характеристика фондової основи експозиції. Зокрема підкреслювалось, що фонди музею на день затвердження концепції нараховували більше 500 експонатів. За своєю тематикою ці експонати певною мірою розкривали теми лише другого розділу. Отже, музею необхідно було проводити додаткове комплектування по всіх темах інших розділів. Фактично можна сказати, що фондова основа експозиції відсутня за винятком окремих тем. Виходячи з цього музей звернувся до української громадськості з закликом про надання допомоги у комплектуванні фондів матеріалами з української військової історії. Відгуки на звернення прийшли не тільки з областей України, а й з США, Великобританії, Канади, Австралії та інших країн. Особливо приємно музею було отримати матеріали від Василя Микитина, які він надіслав з США. Проте від ветеран- ської організації очолюваної генералом армії І. Герасімовим, який у минулому був командувачем Київського військового округу, музей підтримки не отримав.

Головним із проведених у 1996 ропі організаційних заходів музею була підготовка та підписання наказу Міністра оборони України, яким би затверджувалося положення про музей. Робота над наказом розпочалась у квітні і завершилась у вересні виходом наказу, яким було затверджено Положення про Центральний музей Збройних Сил України. Наказ був підписаний Міністром оборони України генерал-лейтенантом О. Кузьмуком. Саме Положення про музей підписано першим заступником Міністра оборони України генерал-полковником I. Біжаном [11].

У наказі зазначено, що загальнодоступний Центральний музей Збройних Сил України необхідно створити до 1 грудня 1997 року. Відповідно до Положення запропоновано внести зміни до штату музею. У Положенні визначені загальні засади, на яких базується діяльність музею, права і обов'язки засновника (Міністерства оборони), організаційна структура музею, основні завдання і напрями його діяльності, керівництво музеєм, матеріально-технічне забезпечення та фінансово-господарська діяльність. Вагомим підгрунтям у розробці та затвердженні цього Положення став Закон України «Про музеї та музейну справу», який був прийнятий Верховною Радою України у березні 1995 року.

Відповідно до наказу музеєм був підготовлений проект змін до штату і поданий до Головного управління виховної роботи Міністерства оборони України. У проекті передбачено створення п'яти відділів: науково-дослідного, експозиційного, фондового, культурно-освітнього та адміністративно-господарчого. Чисельність працівників музею було запропоновано до- 
вести до 55 чоловік. Проте це не вдалося досягти.

Головним напрямом у діяльності музею одразу було обрано комплектування фондів. Це була цілеспрямована робота у військових частинах, військових базах та інших підрозділах, робота з ветеранами. Велику допомогу у комплектуванні фондів музею речовим майном (зразками форми одягу, знаками розрізнення та іншим) радянського періоду надав заступник начальника музею підполковник Бойко Микола Петрович. Він прийшов у музей не надовго, як вважав, у грудні 1996 року. Проте пропрацював у музеї до березня 1998 року і зробив свій внесок у його становлення. Саме його, раніше набутий досвід роботи у ранзі помічника начальника Тилу Збройних сил України дозволив нам забрати до музейної збірки усе можливе зі складів речового майна.

За перший рік роботи колектив музею зібрав 2260 експонатів. 3 цього числа було зібрано 1368 предметів основного фонду. Найважливішим придбанням музею у 1996 році $є$ речі, передані першим міністром оборони України генерал-полковником К. Морозовим, вперше офіційно виготовлені в Україні прапори видів Збройних Сил, проекти, ескізи форми одягу з Науково-технічної лабораторії по розробці форми одягу (ліквідована 1 грудня 1995 року), матеріали 3 міжнародних навчань «Партнерство заради миру», про участь Збройних Сил України у миротворчих силах ООН, придбання френча сотника Української Галицької армії. Структура основного фонду музею склалася така: речовий - 588; образотворчий - 94; декоративно-прикладний - 20: письмові - 229; нумізматика - 167; фотографії - 222; інші - 548.

Багато експонатів уже тоді можна було віднести до розряду носіїв історичної інформації. Наприклад, форма одягу гене- рал-полковника Костянтина Морозова радикально відрізнялася від форми одягу генералів, яка вживалася у військах. Чого варті також власноручні ескізи і пропозиції до розробки форми одягу К. Морозова, начальника Генерального штабу Збройних Сил України генерал-полковника Анатолія Лопати та старшого прапорщика Івана Ріпки. До історичних матеріалів можна віднести і такий несподіваний на той час для українського військового музею експонат як польова форма одягу полковника Сухопутних військ армії США Дугласа Тайстада, який брав участь у навчаннях «Щит миру - 96» та багато інших матеріалів. Цей експонат зібрав для музею під час навчань офіцер Головного управління виховної роботи Міністерства оборони України полковник Микола Шульга.

Проте у музеї була відсутня облікова документація - облікові інвентарні книги, акти прийому музейних предметів встановленого зразка. Не було й коштів на їх виготовлення. Зазначу, що питання фінансового забезпечення музею не було вирішеним. Музей не мав власного розрахункового рахунку і відповідно не міг здійснювати фінансове планування та проводити відповідні фінансові операції. Це була гостра проблема. Допомогу та підтримку діяльності музею у цьому надали начальник ЦКПД 3С України полковник Сергій Олександрович Заровний та головний бухгалтер Алла Федорівна Пашинська. Загалом колектив Будинку офіцерів приязно та дружньо відносився до нелегкого становлення Музею Збройних сил України. Полковник О. Заровний за кошти підпорядкованої йому установи оплатив роботи 3 виготовлення повного комплекту книг з обліку музейних фондів, інвентарних карток та актів прийому і передав нам для роботи.

Якщо музей не говорить із суспільством та громадою своєю музейною мовою, мо- 
вою нових експозицій та виставок, то такий музей у просторі культури відсутній. Відсутність постійної експозиції спонукала до започаткування виставкової діяльності та проведення виставок. Найперша виставка була скоріше символічною - це виставка Перших надходжень. Ї̈̈ приурочили до Міжнародного дня музеїв 18 травня, яке на той час ще не усі й музеї відзначали. Символізм полягав у тому, що у цей день заявив про себе Музей Збройних сил України, який взяв за основу професійні стандарти Міжнародної ради музеїв ЮНЕСКО.

Колектив музею працював над створенням виставки до 5-ї річниці Збройних Сил України 6 грудня 1996 року. Вона стала результатом однорічної праці невеликого музейного колективу. Створення та відкриття виставки стало питанням перевірки музею на його функціональну придатність. У створенні виставки Музею надавали допомогу не тільки керівництво Міністерства оборони і Генерального штабу, а й Адміністрація Президента України та командування Національної Гвардії України. За їх сприяння в експозиції виставки експонувалися такі нагороди України як орден Богдана Хмельницького трьох ступенів, орден «За мужність» трьох ступенів і прапор 3-ї Залізної стрілецької дивізії Армії Української Народної Республіки, який з 1920 року зберігався за кордоном і був переданий Україні у 1991 році.

Виставку назвали «П'ятиріччя». В експозиції цієї виставки було розміщено понад 300 експонатів з основного фонду, які розкривають період формування, становлення і функціонування Української армії за ці п'ять років. Тематика виставки охоплювала майже усі сторони 3 життя армії. Це і суспільно-політична ситуація в Україні на початку 90-х років, здобуття незалежності України і боротьба за утворення власної армії, це діяльність міністрів оборони України - генерал-полковника К. Морозова, генерала армії України В. Раденького, В. Шмарова, це і розповідь про види Збройних Сил України - Сухопутні війська, Військово-Повітряні і Військово-Морські Сили, Сили Протиповітряної оборони, про миротворчу діяльність українських підрозділів у колишній Югославії і в Анголі, про спільні міжнародні навчання «Щит миру - 96», про розробку і впровадження військової форми одягу і також про армійський туризм, культуру і спорт.

Висновки. Формування військової музейної справи розпочалося із створення Музею Збройних Сил України. Започаткування його роботи проходило в умовах трансгресивних процесів у суспільстві, скорочення військ та відзначається відсутністю комплексного підходу у забезпеченні його діяльності та розбудови. В цих умовах було обрано головні напрями утвердження музею, підняття його статусу та визначення ролі і місця в системі виховної роботи у Збройних Силах України. Колектив музею опанував усі види діяльності, набув досвіду музейної практики і засвідчив свою готовність до виконання завдань за призначенням. Було визначено, що музей продовжить свою діяльність у статусі головного військового музею країни.

\section{СПИСОК ВИКОРИСТАНОЇ ЛІТЕРАТУРИ}

1. Мокроусова О. До історії створення військового музею в Києві // Науковий вісник Національного музею історії України. Випуск 2. К.: НМІУ. 2017.

2. Карпов В.В. 100 років з дня створення першого військово-історичного музею в Україні // Український військовий музей К.: НВІМУ. № 2. 2010. 
3. Карпов В.В. Музейна справа у Збройних силах України (1996-2006). К.: ЦМЗСУ. 2007. 96 с., іл.

4. Статистичні дані укладено на підставі доповідей начальників музеїв на Всеармійських зборах начальників музеїв військових округів та флотів. Одеса. 1989 р. Особистий архів автора.

5. Кобзар А. Становлення та розвиток структур виховної роботи у Збройних Силах України. // Автореф. дис. на здоб. наук. ступ. к. і. н. Київ.: Національний університет оборони України імені Івана Черняховського. 2013. 16 с.; Виховна робота у Збройних Силах України: підруч. [А. О. Кобзар, О.В. Копаниця, В. М. Грицюк та ін.]. Чернівці: Місто, 2011. 408 с.

6. Наказ начальника Головного управління виховної роботи Міністерства оборони України «Про призначення майора Карпова Віктора Васильовича начальником Музею Збройних Сил України» від 11 жовтня 1995 року № 022.

7. Директива начальника Генерального штабу Збройних Сил України від 9 листопада 1995 року №ДГШ-54 «Про організацію діяльності Музею Збройних Сил України».

8. Наказ начальника Головного управління виховної роботи Міністерства оборони України від 14 листопада 1995 року № 46 «Про призначення комісії для передачі фондів військово-історичного музею Центру культури, просвіти і дозвілля Збройних Сил України до Музею Збройних Сил України».

9. Котвіцький В.В. Створення та розвиток музейних інституцій в Збройних Силах України (1991-1996 рр.) // Воєнно-історичний вісник. К.: Національний університет оборони України, 2017. № 1(23). C. 68-74.

10. Наказ Міністерства культури і мистецтв України та Міністерства внутрішніх справ України від 05.12.96 № 579/926 «Про затвердження комплексної програми «Музейна безпека». С.3.

11. Наказ Міністра оборони України від 12 вересня 1996 року № 260 «Про затвердження Положення про Центральний музей Збройних Сил України».

\section{REFERENCES}

1. Mokrousova O. Do istoriï stvorennja vijs'kovogo muzeju v Kiєvi // Naukovij visnik Nacional'nogo muzeju istoriï Ukraïni. Vipusk 2. K.: NMIU. 2017. [in Ukraine]

2. Karpov V.V. 100 rokiv z dnja stvorennja pershogo vijs'kovo-istorichnogo muzeju v Ukraïni // Ukraïns'kij vijs'kovij muzej K.: NVIMU. № 2. 2010. [in Ukraine]

3. Karpov V.V. Muzejna sprava u Zbrojnih silah Ukraïni (1996-2006). K.: CMZSU. 2007. 96 s., il. [in Ukraine]

4. Statystychni dani ukladeno na pidstavi dopovidej nachaljnykiv muzegv na Vsearmijsjkykh zborakh nachaljnykiv muzejiv vijsjkovykh okrughiv ta flotiv. Odesa.1989 r. Osobystyj arkhiv avtora. [in Ukraine]

5. Kobzar A. Stanovlennja ta rozvytok struktur vykhovnoji roboty u Zbrojnykh Sylakh Ukrajiny. // Avtoref. dys. na zdob. nauk. stup. k. i. n. Kyjiv.: Nacionaljnyj universytet oborony Ukrajiny imeni Ivana Chernjakhovsjkogho. 2013. 16 s.; Vykhovna robota u Zbrojnykh Sylakh Ukrajiny: pidruch. [A. O. Kobzar, O.V. Kopanycja, V.M. Ghrycjuk ta in.]. Chernivci: Misto, 2011. 408 s. [in Ukraine] 
6. Nakaz nachaljnyka Gholovnogho upravlinnja vykhovnoji roboty Ministerstva oborony Ukrajiny «Pro pryznachennja majora Karpova Viktora Vasyljovycha nachaljnykom Muzeju Zbrojnykh Syl Ukrajiny» vid 11 zhovtnja 1995 roku \# 022. [in Ukraine]

7. Dyrektyva nachaljnyka Gheneraljnogho shtabu Zbrojnykh Syl Ukrajiny vid 9 lystopada 1995 roku \#DGhSh-54 «Pro orghanizaciju dijaljnosti Muzeju Zbrojnykh Syl Ukrajiny». [in Ukraine]

8. Nakaz nachaljnyka Gholovnogho upravlinnja vykhovnoji roboty Ministerstva oborony Ukrajiny vid 14 lystopada 1995 roku \# 46 «Pro pryznachennja komisiji dlja peredachi fondiv vijsjkovo-istorychnogho muzeju Centru kuljtury, prosvity i dozvillja Zbrojnykh Syl Ukrajiny do Muzeju Zbrojnykh Syl Ukrajiny». [in Ukraine]

9. Kotvicjkyj V.V. Stvorennja ta rozvytok muzejnykh instytucij v Zbrojnykh Sylakh Ukrajiny (1991-1996 rr.) // Vojenno-istorychnyj visnyk. K.: Nacionaljnyj universytet oborony Ukrajiny, 2017. \#1(23). S. 68-74. [in Ukraine]

10. Nakaz Ministerstva kuljtury i mystectv Ukrajiny ta Ministerstva vnutrishnikh sprav Ukrajiny vid 05.12.96 \# 579/926 «Pro zatverdzhennja kompleksnoji proghramy «Muzejna bezpeka». C. 3. [in Ukraine]

11. Nakaz Ministra oborony Ukrajiny vid 12 veresnja 1996 roku \# 260 «Pro zatverdzhennja Polozhennja pro Centraljnyj muzej Zbrojnykh Syl Ukrajiny». [in Ukraine]

Karpov $V_{\cdot} V_{\text {, }}$

Kyiv, National University of Life and

Environmental Sciences of Ukraine

ORCID: https://orcid.org/0000-0002-3446-9187

\section{FORMATION OF MILITARY MUSEUM BUSINESS IN UKRAINE IN THE PERIOD OF SOCIO-POLITICAL TRANSFORMATION (1989-1996)}

The purpose of the study is to highlight the activities of military museums during the changing values of society and the transformation of the state system and the formation of the foundations of museum work in the Armed Forces of Ukraine. Research methods. Systematic and comprehensive approach in the disclosure of the purpose, the use of comparative analysis, historical and chronological, biographical, historiographical methods contributed to the achievement of significant theoretical results. The scientific novelty of the study lies in the formulation and development of a topical topic, which in the scientific dimension has received insufficient coverage and is studied on empirical experience. The idea is substantiated that the activity of military museums does not always meet the needs of society, requires state regulation and support. Conclusions. It is stated that military museum studies in the period under study was marked by the search for a new model of functioning of military museums, which was dictated by changes in public mood, political and economic system. It is noted that such a model was developed by the Museum of the History of the Far Eastern Military District and was to give the museum independence in making decisions on the operational management of its activities. However, changes in values have reduced the role of museums in the social process. Such a model was used to create the Museum of the Armed Forces of Ukraine as a system-forming element of military museum work.

Key words: military museum, armed forces, USSR, Ukraine, society, values, transgression. 